\title{
Antibacterial power of Olea Europaea extracts from different Moroccan regions
}

\author{
Hajar Lahdibi Sahraoui ${ }^{1,2}$, Aicha Qasmaoui ${ }^{1}$, Réda Charof $^{1}$, Jamila Hamamouchi ${ }^{1}$ and El Hassan Berny ${ }^{2}$ \\ ${ }^{1}$ Laboratory of Epidemic Diseases, Department of Medical Bacteriology, National Institute of Hygiene, Avenue Ibn Batouta, \\ Rabat, Morocco \\ ${ }^{2}$ Laboratory of Biology and Health, Department of Biology, Faculty of Science, Ibn Tofail University, Kenitra, Morocco
}

\begin{abstract}
The discovery of antibiotics has always been a medical advance that has improved the prognosis of infections. However, resistance to these products has evolved into a major health problem. Some diseases are even resistant to all antibiotics currently available on the market. A reduction in the use of antibiotics must be based on other approaches, namely the use of alternative treatments to antibiotics, such as phytotherapy. In the same objective our study focused on the research of the antibacterial power of Olea Europaea known for its various medicinal properties. 31 bacterial strains were tested for their susceptibility using the agar diffusion method, and we determined their MIC by the micro titration technique on microplates. Five bacteria belonged to the American collection (ATCC) and 26 strains isolated from nosocomial infections between the period of 2011 and 2015 . We noticed that our aqueous, methanolic, ethanolic and ethyl acetate extracts are active against all tested bacteria. On the other hand, we observed that the hexane and dichloromethane extracts showed no inhibition effect on all the bacteria tested. The methanolic extract showed a higher MIC against ESBL enterobacteria (E. coli, E. cloacae, P. mirabilis) and imipenem-resistant A. baumanii. The lowest MIC was $1.56 \mathrm{ug} / \mathrm{ml}$. Key words: antibiotic resistance, antibacterial activity, Olea Europaea, medicinal plants.
\end{abstract}

\section{Introduction}

Hospital infections are a major public health problem worldwide, including Morocco [1]. The use of drugs is extremely important for the treatment of these infections, but it is also subject to an important selection pressure that affects many bacteria and the development of resistance to the most prescribed antibiotics. The use of new and more durable antibiotics is the most effective solution to this problem [2]. Plant extracts and essential oils have been a natural source of antimicrobial mixtures or pure compounds for centuries [3]. As for Olea europaea (Olive), it is a most important fruit tree. It is native to the Mediterranean region such as Palestine, Syria, Spain, Italy, Greece, France, Turkey, Algeria and Morocco [4, 5]. In addition, the leaf is a main site of plant metabolism best known at the level of primary and secondary plant products and can be considered as a potential source of bioactive compounds [7].

\section{Material and methods}

\subsection{Plant collection}

Olive leaves were collected between September and December 2014 in several Moroccan provinces (Meknes, Fquih Ben Salah, Taza and Ouezzane). They were cleaned, washed and then dried at room temperature. The dried leaves were ground into a fine powder using and stored in an airtight container away from light until extraction to avoid oxidation.

\section{3 reparation of the olive leaf extracts}

The extracts (with the solvents: water, Dichloromethane, Ethanol, Methanol, Hexane and Ethyl acetate) were obtained by Soxhlet extraction of $100 \mathrm{~g}$ of leaves for $24 \mathrm{~h}$ in $700 \mathrm{ml}$ of used solvent. The result was subjected to drying in a rotary evaporator, after which the leaf extract was used for further analysis [6].

\subsection{Microorganisms used}

31 bacterial strains were tested: five represent ATCC strains and 26 strains were from nosocomial infections of various origins (Table 1).

These strains were stored in the strain library of the Laboratory of Epidemic Diseases at the National Institute of Hygiene in Rabat. 
Table 1. Bacterial strains from different origins

\begin{tabular}{|c|c|c|c|}
\hline microbial group & organisms used & Strain origin & phenotype \\
\hline \multirow{18}{*}{ Enterobacteriae Gram - } & Escherichia coli (I) & CBUE & ESBL \\
\hline & Escherichia coli (2) & Central Catheter & ESBL \\
\hline & Escherichia coli (3) & Pus & ESBL \\
\hline & klebsiella pneumonia (I) & CBUE & ESBL \\
\hline & klebsiella pneumonia (2) & Central Catheter & ESBL \\
\hline & klebsiella pneumonia (3) & Pus & ESBL \\
\hline & Enterobacter Cloacae (I) & CBUE & ESBL \\
\hline & Enterobacter Cloacae (2) & Central Catheter & ESBL \\
\hline & Enterobacter Cloacae (3) & Pus & ESBL \\
\hline & Proteus Mirabilis (1) & CBUE & ESBL \\
\hline & Proteus Mirabilis(2) & Pus & ESBL \\
\hline & Morganella Morganii & Pus & ESBL \\
\hline & Escherichia coli (4) & CBUE & HLP \\
\hline & Escherichia coli (5) & CBUE & HLC \\
\hline & Escherichia coli (6) & CBUE & LLC \\
\hline & Escherichia coli (7) & CBUE & LLP \\
\hline & Escherichia coli (8) & Liquide d'ascite & HLP \\
\hline & Escherichia coli (9) & Pus & LLP \\
\hline \multirow{6}{*}{ Not Enterobacteriae Gram - } & Pseudomonas aeruginosa (1) & CBUE & ESBL \\
\hline & Pseudomonas aeruginosa (2) & CBUE & Multiresistant \\
\hline & Acinetobacter Baumanii (1) & CBUE & IPM -R \\
\hline & Acinetobacter Baumanii (2) & Central Catheter & IPM -R \\
\hline & Acinetobacter Baumanii (3) & Pus & IPM -R \\
\hline & Acinetobacter Baumanii (4) & Traumatology & IPM -R \\
\hline \multirow[t]{2}{*}{ Gram +} & staphylococcus aureus (I) & Central Catheter & Meti- R \\
\hline & staphylococcus aureus (2) & Pus & Meti- R \\
\hline
\end{tabular}

\subsection{Culture media and antimicrobial test}

Microbial cultures, freshly grown at $37^{\circ} \mathrm{C} / 24 \mathrm{~h}$ were appropriately diluted in sterile normal saline $(0.9 \%$ $\mathrm{NaCl}$ ) to obtain the cell suspension previously adjusted using the $0.5 \mathrm{McF}$ arland standard and a turbidity of $105 \mathrm{CFU} / \mathrm{ml}$.

\subsection{Minimum inhibitory concentration (MIC)}

The determination of the MIC of plant extracts against microbial strains was performed according to the microtitration technique described by Eloff [8].

\subsection{Minimum bactericidal concentration (MBC)}

Antimicrobial activity was performed by the MullerHinton (MH) agar medium diffusion method [7]. Wells of $6 \mathrm{~mm}$ diameter were perforated in the agar medium and filled with $50 \mu \mathrm{l}$ of plant extracts. The dishes were incubated for $24 \mathrm{~h}$ at $37^{\circ} \mathrm{C}$.

Antimicrobial activity was evaluated by measuring the zone of inhibition against the tested microorganism.

To assess the MBC, $100 \mu \mathrm{L}$ of each sample, in which no microbial growth was observed, was spread in Muller-Hinton agar (MH). The plates were incubated at the appropriate temperature for $24 \mathrm{~h}$. BMC was defined as the lowest concentration at which bacterial growth was completely inhibited [910].

\section{Results}




\subsection{Diameter of inhibition}

During the screening of the antibacterial activity of the different extracts of olea europeae, the inhibition diameters obtained are mentioned in the tables $(2$, and 3).

Table 2. Screening Antibacterial activity of aqueous, methanolic, dichloromethane and ethanolic extracts of Olive leaves collected in four regions of Morocco

\begin{tabular}{|c|c|c|c|c|c|c|c|c|c|c|c|c|c|c|c|c|}
\hline \multirow{3}{*}{$\begin{array}{l}\text { Bacterial } \\
\text { strains tested }\end{array}$} & \multicolumn{16}{|c|}{ Inhibition zone diameters $(\mathrm{mm})$} \\
\hline & \multicolumn{2}{|c|}{$\begin{array}{l}\text { Meknes } \\
\text { extract }\end{array}$} & \multicolumn{2}{|c|}{$\begin{array}{ll}\text { Fquih } & \text { Ben } \\
\text { Salah } & \\
\text { extract } & \end{array}$} & \multicolumn{2}{|c|}{$\begin{array}{l}\text { Taza } \\
\text { extract }\end{array}$} & \multicolumn{2}{|c|}{$\begin{array}{l}\text { Ouezzane } \\
\text { extract }\end{array}$} & \multicolumn{2}{|c|}{$\begin{array}{l}\text { Meknes } \\
\text { extract }\end{array}$} & \multicolumn{2}{|c|}{$\begin{array}{l}\text { Fquih ben } \\
\text { Salah } \\
\text { extract }\end{array}$} & \multicolumn{2}{|c|}{$\begin{array}{l}\text { Taza } \\
\text { extract }\end{array}$} & \multicolumn{2}{|c|}{$\begin{array}{l}\text { Ouezzane } \\
\text { extract }\end{array}$} \\
\hline & $\mathbf{A E}$ & ME & $\mathbf{A E}$ & ME & $\mathbf{A E}$ & ME & $\mathbf{A E}$ & ME & DE & EE & DE & $\mathbf{E E}$ & DE & EE & DE & EE \\
\hline Escherichia coli ATCC 25922 & 9 & 9 & 0 & 14 & 9 & 10 & 13 & 12 & $\mathbf{0}$ & 15 & 0 & 15 & 0 & 13 & 0 & 12 \\
\hline Staphylococcus aureus ATCC 25923 & 12 & 14 & 0 & 13 & 15 & 14 & 17 & 14 & $\mathbf{0}$ & 17 & 0 & 15 & 0 & 15 & 0 & 15 \\
\hline Pseudomonas aeruginosa ATCC 27853 & 12 & 13 & 9 & 13 & 12 & 10 & 19 & 12 & $\mathbf{0}$ & 12 & 0 & 12 & 0 & 10 & 0 & 10 \\
\hline Proteus vulgaris ATCC 13315 & 11 & 10 & 0 & 12 & 11 & 10 & 14 & 10 & $\mathbf{0}$ & 15 & 0 & 15 & 0 & 11 & 0 & 11 \\
\hline Citrobacter Freundii ATCC 8090 & 15 & 0 & 11 & 13 & 11 & 9 & 11 & 10 & $\mathbf{0}$ & 16 & 0 & 13 & 0 & 12 & 0 & 12 \\
\hline Escherichia coli (1) & 12 & 10 & 0 & 13 & 12 & 10 & 16 & 10 & $\mathbf{0}$ & 10 & 0 & 13 & 0 & 10 & 0 & 12 \\
\hline Escherichia coli (2) & 10 & 11 & 0 & 14 & 0 & 9 & 12 & 10 & 0 & 12 & 0 & 14 & 0 & 10 & 0 & 14 \\
\hline Escherichia coli (3) & 11 & 10 & 0 & 13 & 0 & 11 & 16 & 11 & $\mathbf{0}$ & 12 & 0 & 13 & 0 & 10 & 0 & 10 \\
\hline klebsiella pneumonia (1) & 10 & 9 & 0 & 12 & 0 & 9 & 14 & 10 & $\mathbf{0}$ & 9 & 0 & 12 & 0 & 10 & 0 & 11 \\
\hline klebsiella pneumonia (2) & 8 & 9 & 0 & 11 & 0 & 10 & 13 & 10 & $\mathbf{0}$ & 12 & 0 & 13 & 0 & 12 & 0 & 10 \\
\hline klebsiella pneumonia (3) & 10 & 10 & 0 & 11 & 9 & 10 & 15 & 11 & $\mathbf{0}$ & 11 & 0 & 12 & 0 & 12 & 0 & 10 \\
\hline Enterobacter Cloacae (1) & 11 & 10 & 0 & 11 & 10 & 10 & 14 & 10 & $\mathbf{0}$ & 11 & 0 & 12 & 0 & 11 & 0 & 10 \\
\hline Enterobacter Cloacae (2) & 10 & 10 & 0 & 13 & 0 & 0 & 13 & 10 & $\mathbf{0}$ & 12 & 0 & 12 & 0 & 12 & 0 & 11 \\
\hline Enterobacter Cloacae (3) & 10 & 10 & 0 & 13 & 0 & 10 & 16 & 10 & $\mathbf{0}$ & 10 & 0 & 11 & 0 & 11 & 0 & 12 \\
\hline Proteus Mirabilis (1) & 12 & 9 & 8 & 13 & 8 & 10 & 13 & 10 & $\mathbf{0}$ & 10 & 0 & 12 & 0 & 10 & 0 & 10 \\
\hline Proteus Mirabilis(2) & 14 & 12 & 9 & 13 & 14 & 12 & 15 & 12 & $\mathbf{0}$ & 14 & 0 & 15 & 0 & 10 & 0 & 10 \\
\hline Morganella Morganii & 11 & 10 & 0 & 11 & 9 & 10 & 14 & 11 & $\mathbf{0}$ & 10 & 0 & 11 & 0 & 12 & 0 & 10 \\
\hline Escherichia coli (4) & 10 & 12 & 0 & 14 & 0 & 10 & 14 & 10 & $\mathbf{0}$ & 13 & 0 & 15 & 0 & 11 & 0 & 12 \\
\hline Escherichia coli (5) & 10 & 10 & 0 & 13 & 9 & 10 & 14 & 10 & $\mathbf{0}$ & 10 & 0 & 14 & 0 & 11 & 0 & 10 \\
\hline Escherichia coli (6) & 9 & 10 & 0 & 14 & 0 & 10 & 11 & 11 & $\mathbf{0}$ & 12 & 0 & 13 & 0 & 11 & 0 & 10 \\
\hline Escherichia coli (7) & 12 & 10 & 0 & 12 & 10 & 10 & 14 & 10 & $\mathbf{0}$ & 11 & 0 & 12 & 0 & 11 & 0 & 10 \\
\hline Escherichia coli (8) & 11 & 11 & 0 & 14 & 0 & 10 & 11 & 11 & $\mathbf{0}$ & 13 & 0 & 15 & 0 & 12 & 0 & 12 \\
\hline Escherichia coli (9) & 9 & 11 & 0 & 14 & 12 & 9 & 11 & 10 & $\mathbf{0}$ & 11 & 0 & 13 & 0 & 10 & 0 & 10 \\
\hline Pseudomonas aeruginosa (1) & 11 & 10 & 0 & 14 & 10 & 12 & 14 & 10 & $\mathbf{0}$ & 10 & 0 & 13 & 0 & 10 & 0 & 9 \\
\hline Pseudomonas aeruginosa (2) & 10 & 11 & 0 & 12 & 9 & 10 & 13 & 10 & $\mathbf{0}$ & 14 & 0 & 12 & 0 & 12 & 0 & 10 \\
\hline Acinetobacter Baumanii (1) & 13 & 11 & 0 & 12 & 9 & 13 & 15 & 13 & $\mathbf{0}$ & 10 & 0 & 12 & 0 & 12 & 0 & 10 \\
\hline Acinetobacter Baumanii (2) & 13 & 11 & 0 & 13 & 11 & 12 & 18 & 12 & $\mathbf{0}$ & 12 & 0 & 14 & 0 & 11 & 0 & 11 \\
\hline Acinetobacter Baumanii (3) & 11 & 10 & 0 & 10 & 0 & 10 & 13 & 10 & $\mathbf{0}$ & 12 & 0 & 10 & 0 & 10 & 0 & 10 \\
\hline Acinetobacter Baumanii (4) & 13 & 16 & 0 & 16 & 12 & 11 & 16 & 11 & $\mathbf{0}$ & 12 & 0 & 12 & 0 & 12 & 0 & 12 \\
\hline staphylococcus aureus (1) & 19 & 12 & 0 & 14 & 17 & 10 & 20 & 10 & $\mathbf{0}$ & 10 & 0 & 12 & 0 & 11 & 0 & 10 \\
\hline staphylococcus aureus (2) & 17 & 13 & 0 & 15 & 13 & 12 & 16 & 11 & $\mathbf{0}$ & 13 & 0 & 15 & 0 & 12 & 0 & 12 \\
\hline
\end{tabular}

AE: aqueous extracts, ME: Methanolic extracts, DE: Dichloromethane extracts, EE: ethanolic extracts (-): no activity

Table 3. Screening of the antibacterial activity and Minimum inhibitory concentration of hexane and ethyl acetate extracts of olive leaves collected in four regions of Morocco.

\begin{tabular}{|c|c|c|c|c|c|c|c|c|c|c|c|c|c|c|c|c|}
\hline \multirow{2}{*}{$\begin{array}{l}\text { Bacterial } \\
\text { strains tested }\end{array}$} & \multicolumn{16}{|c|}{ Inhibition zone diameters (mm) } \\
\hline & \multicolumn{2}{|c|}{$\begin{array}{l}\text { Meknes } \\
\text { extract }\end{array}$} & \multicolumn{2}{|c|}{$\begin{array}{l}\text { Fquih ben } \\
\text { Salah } \\
\text { extract }\end{array}$} & \multicolumn{2}{|c|}{$\begin{array}{l}\text { Taza } \\
\text { extract }\end{array}$} & \multicolumn{2}{|c|}{$\begin{array}{l}\text { Ouezzane } \\
\text { extract }\end{array}$} & \multicolumn{2}{|c|}{$\begin{array}{l}\text { Meknes } \\
\text { extract }\end{array}$} & \multicolumn{2}{|c|}{$\begin{array}{l}\text { Fquih } \quad \text { Ben } \\
\text { Salah } \\
\text { extract }\end{array}$} & \multicolumn{2}{|c|}{$\begin{array}{l}\text { Taza } \\
\text { extract }\end{array}$} & \multicolumn{2}{|c|}{$\begin{array}{l}\text { Ouezzane } \\
\text { extract }\end{array}$} \\
\hline Escherichia coli ATCC 25922 & 0 & 16 & 0 & 14 & 0 & 17 & 0 & 12 & - & 0,8 & - & 1,56 & - & 0,39 & - & 3,13 \\
\hline Staphylococcus aureus ATCC 25923 & 0 & 24 & 0 & 14 & 0 & 20 & 0 & 15 & - & 3,1 & - & 1,56 & - & 0,78 & - & 3,13 \\
\hline Pseudomonas aeruginosa ATCC 27853 & 0 & 20 & 0 & 20 & 0 & 20 & 0 & 15 & - & 1,6 & - & 1,56 & - & 0,39 & - & 3,13 \\
\hline Citrobacter Freundii ATCC 8090 & 0 & 30 & 0 & 21 & 0 & 26 & 0 & 20 & - & 0,8 & - & 0,78 & - & 0,78 & - & 1,56 \\
\hline Escherichia coli (1) & 0 & 19 & 0 & 14 & 0 & 17 & 0 & 12 & - & 1,6 & - & 3,125 & - & 1,56 & - & 6,25 \\
\hline Escherichia coli (2) & 0 & 17 & 0 & 12 & 0 & 17 & 0 & 14 & - & 1,6 & - & 3,125 & - & 0,78 & - & 6,25 \\
\hline Escherichia coli (3) & 0 & 17 & 0 & 15 & 0 & 16 & 0 & 11 & - & 1,6 & - & 1,56 & - & 0,78 & - & 3,13 \\
\hline klebsiella pneumonia (1) & 0 & 15 & 0 & 17 & 0 & 15 & 0 & 12 & - & 1,6 & - & 1,56 & - & 1,56 & - & 6,25 \\
\hline klebsiella pneumonia (2) & 0 & 20 & 0 & 15 & 0 & 14 & 0 & 11 & - & 1,6 & - & 3,125 & - & 0,78 & - & 3,13 \\
\hline klebsiella pneumonia (3) & 0 & 18 & 0 & 18 & 0 & 20 & 0 & 11 & - & 1,6 & - & 3,125 & - & 0,78 & - & 6,25 \\
\hline Enterobacter Cloacae (1) & 0 & 16 & 0 & 14 & 0 & 15 & 0 & 13 & - & 1,6 & - & 1,56 & - & 0,78 & - & 3,13 \\
\hline Enterobacter Cloacae (2) & 0 & 16 & 0 & 16 & 0 & 17 & 0 & 12 & - & 1,6 & - & 1,56 & - & 0,39 & - & 3,13 \\
\hline Proteus Mirabilis (1) & 0 & 18 & 0 & 13 & 0 & 14 & 0 & 12 & - & 1,6 & - & 1,56 & - & 0,78 & - & 6,25 \\
\hline Proteus Mirabilis(2) & 0 & 20 & 0 & 20 & 0 & 20 & 0 & 15 & - & 1,6 & - & 1,56 & - & 0,78 & - & 1,56 \\
\hline Morganella Morganii & 0 & 19 & 0 & 21 & 0 & 18 & 0 & 11 & - & 1,6 & - & 1,56 & - & 1,56 & - & 3,13 \\
\hline Escherichia coli (4) & 0 & 25 & 0 & 22 & 0 & 20 & 0 & 11 & - & 1,6 & - & 1,56 & - & 0,78 & - & 3,13 \\
\hline Escherichia coli (5) & 0 & 19 & 0 & 13 & 0 & 16 & 0 & 10 & - & 1,6 & - & 1,56 & - & 0,78 & - & 3,13 \\
\hline
\end{tabular}




\begin{tabular}{|l|l|l|l|l|l|l|l|l|l|l|l|l|l|l|l|l|}
\hline Escherichia coli (6) & 0 & 15 & 0 & 15 & 0 & 12 & 0 & 12 & - & 1,6 & - & 3,125 & - & 1,56 & - & 3,13 \\
\hline Escherichia coli (7) & 0 & 20 & 0 & 19 & 0 & 15 & 0 & 12 & - & 1,6 & - & 1,56 & - & 0,78 & - & 3,13 \\
\hline Escherichia coli (8) & 0 & 24 & 0 & 17 & 0 & 18 & 0 & 11 & - & 1,6 & - & 3,125 & - & 0,78 & - & 3,13 \\
\hline Escherichia coli (9) & 0 & 20 & 0 & 15 & 0 & 18 & 0 & 17 & - & 1,6 & - & 1,56 & - & 0,78 & - & 3,13 \\
\hline Pseudomonas aeruginosa (1) & 0 & 18 & 0 & 13 & 0 & 14 & 0 & 12 & - & 1,6 & - & 1,56 & - & 0,39 & - & 3,13 \\
\hline Pseudomonas aeruginosa (2) & 0 & 20 & 0 & 20 & 0 & 20 & 0 & 15 & - & 1,6 & - & 3,125 & - & 0,78 & - & 3,13 \\
\hline Acinetobacter Baumanii (1) & 0 & 25 & 0 & 27 & 0 & 22 & 0 & 14 & - & 1,6 & - & 1,56 & - & 1,56 & - & 3,13 \\
\hline Acinetobacter Baumanii (2) & 0 & 18 & 0 & 14 & 0 & 19 & 0 & 12 & - & 1,6 & - & 1,56 & - & 0,78 & - & 3,13 \\
\hline Acinetobacter Baumanii (3) & 0 & 20 & 0 & 20 & 0 & 18 & 0 & 11 & - & 1,6 & - & 3,125 & - & 0,78 & - & 1,56 \\
\hline Acinetobacter Baumanii (4) & 0 & 22 & 0 & 19 & 0 & 24 & 0 & 12 & - & 1,6 & - & 1,56 & - & 0,39 & - & 3,13 \\
\hline staphylococcus aureus (1) & 0 & 20 & 0 & 17 & 0 & 17 & 0 & 15 & - & 1,6 & - & 1,56 & - & 0,39 & - & 3,13 \\
\hline staphylococcus aureus (2) & 0 & 28 & 0 & 27 & 0 & 23 & 0 & 14 & - & 0,8 & - & 1,56 & - & 1,56 & - & 1,56 \\
\hline
\end{tabular}

HE: hexane extracts, EAE: ethyl acetate extracts, (-): no activity

\subsection{Minimum inhibitory concentration of extracts}

The minimum inhibitory concentration of our extracts was performed in microplates, the results obtained are shown in tables ( 3 and 4 ) for ethanolic, dichloromethane, hexanolic, and ethyl acetate extracts.

Table 4. Minimum inhibitory concentration of aqueous, methanolic, dichloromethane and ethanolic extracts of leaves collected in four regions of Morocco

\begin{tabular}{|c|c|c|c|c|c|c|c|c|c|c|c|c|c|c|c|c|}
\hline \multirow{3}{*}{$\begin{array}{l}\text { Bacterial } \\
\text { strains tested }\end{array}$} & \multicolumn{16}{|c|}{ Minimum inhibitory concentration $(\mu \mathrm{g} / \mathrm{ml})$} \\
\hline & \multicolumn{2}{|c|}{$\begin{array}{l}\text { Meknes } \\
\text { extract }\end{array}$} & \multicolumn{2}{|c|}{$\begin{array}{l}\text { Fquih Ben } \\
\text { Salah } \\
\text { extract }\end{array}$} & \multicolumn{2}{|c|}{$\begin{array}{l}\text { Taza } \\
\text { extract }\end{array}$} & \multicolumn{2}{|c|}{$\begin{array}{l}\text { Ouezzane } \\
\text { extract }\end{array}$} & \multicolumn{2}{|c|}{$\begin{array}{l}\text { Meknes } \\
\text { extract }\end{array}$} & \multicolumn{2}{|c|}{$\begin{array}{l}\text { Fquih Ben } \\
\text { Salah } \\
\text { extract }\end{array}$} & \multicolumn{2}{|c|}{$\begin{array}{l}\text { Taza } \\
\text { extract }\end{array}$} & \multicolumn{2}{|c|}{$\begin{array}{l}\text { Ouezzane } \\
\text { extract }\end{array}$} \\
\hline & $\mathrm{AE}$ & ME & $\mathrm{AE}$ & ME & $\mathrm{AE}$ & ME & $\mathrm{AE}$ & ME & $\begin{array}{l}\mathrm{D} \\
\mathrm{E}\end{array}$ & $\mathrm{EE}$ & $\begin{array}{l}\mathrm{D} \\
\mathrm{E}\end{array}$ & $\mathrm{EE}$ & $\mathrm{DE}$ & $\mathrm{EE}$ & $\begin{array}{l}\mathrm{D} \\
\mathrm{E}\end{array}$ & $\mathrm{EE}$ \\
\hline Escherichia coli ATCC 25922 & 6,25 & 1,56 & - & 0,78 & 25 & 3,125 & 25 & 3,125 & - & 3,13 & - & 3,13 & - & 1,56 & - & 6,25 \\
\hline Staphylococcus aureus ATCC 25923 & 6,25 & 1,56 & - & 3,125 & 25 & 6,25 & 12,5 & 6,25 & - & 1,56 & - & 3,13 & - & 1,56 & - & 6,25 \\
\hline Pseudomonas aeruginosa ATCC 27853 & 12,5 & 6,25 & - & 6,25 & 12,5 & 6,25 & 6,25 & 6,25 & - & 1,56 & - & 1,56 & - & 3,125 & - & 6,25 \\
\hline Proteus vulgaris ATCC 13315 & 12,5 & 1,56 & - & 0,78 & 25 & 3,125 & 6,25 & 1,56 & - & 1,56 & - & 6,25 & - & 1,56 & - & 3,13 \\
\hline Citrobacter Freundii ATCC 8090 & 1,56 & 0,78 & - & 0,78 & 25 & 1,56 & 12,5 & 0,78 & - & 3,13 & - & 3,13 & - & 0,78 & - & 3,13 \\
\hline Escherichia coli (1) & 6,25 & 6,25 & - & 3,125 & 25 & 3,125 & 6,25 & 6,25 & - & 1,56 & - & 6,25 & - & 3,125 & - & 3,13 \\
\hline Escherichia coli (2) & 6,25 & 1,56 & - & 1,56 & - & 3,125 & 25 & 3,125 & - & 6,25 & - & 12,5 & - & 3,125 & - & 6,25 \\
\hline Escherichia coli (3) & 6,25 & 3,125 & - & 0,78 & - & 3,125 & 25 & 3,125 & - & 6,25 & - & 12,5 & - & 3,125 & - & 6,25 \\
\hline klebsiella pneumonia (1) & 12,5 & 6,25 & - & 0,78 & - & 6,25 & 25 & 1,56 & - & 6,25 & - & 6,25 & - & 6,25 & - & 6,25 \\
\hline klebsiella pneumonia (2) & 6,25 & 1,56 & - & 1,56 & - & 3,125 & 25 & 3,125 & - & 12,5 & - & 6,25 & - & 6,25 & - & 6,25 \\
\hline klebsiella pneumonia (3) & 12,5 & 6,25 & - & 3,125 & 25 & 3,125 & 25 & 6,25 & - & 6,25 & - & 3,13 & - & 3,125 & - & 6,25 \\
\hline Enterobacter Cloacae (1) & 6,25 & 1,56 & - & 3,125 & 25 & 3,125 & 12,5 & 3,125 & - & 1,56 & - & 12,5 & - & 3,125 & - & 6,25 \\
\hline Enterobacter Cloacae (2) & 6,25 & 3,125 & - & 0,78 & - & 0,78 & 25 & 0,78 & - & 1,56 & - & 6,25 & - & 0,78 & - & 3,13 \\
\hline Enterobacter Cloacae (3) & 6,25 & 3,125 & - & 3,125 & - & 3,125 & 12,5 & 3,125 & - & 1,56 & - & 6,25 & - & 3,125 & - & 6,25 \\
\hline Proteus Mirabilis (1) & 6,25 & 3,125 & - & 0,78 & 25 & 1,56 & 6,25 & 3,125 & - & 1,56 & - & 3,13 & - & 3,125 & - & 6,5 \\
\hline Proteus Mirabilis(2) & 6,25 & 1,56 & - & 1,56 & 25 & 1,56 & 6,25 & 3,125 & - & 3,13 & - & 6,25 & - & 3,125 & - & 6,25 \\
\hline Morganella Morganii & 12,5 & 3,125 & - & 3,125 & 25 & 3,125 & 12,5 & 3,125 & - & 3,13 & - & 12,5 & - & 3,125 & - & 3,13 \\
\hline Escherichia coli (4) & 6,25 & 1,56 & - & 1,56 & - & 1,56 & 25 & 3,125 & - & 6,25 & - & 12,5 & - & 3,125 & - & 6,25 \\
\hline Escherichia coli (5) & 6,25 & 3,125 & - & 1,56 & 25 & 1,56 & 12,5 & 3,125 & - & 6,25 & - & 6,25 & - & 3,125 & - & 6,25 \\
\hline Escherichia coli (6) & 6,25 & 1,56 & - & 1,56 & - & 3,125 & 6,25 & 3,125 & - & 12,5 & - & 6,25 & - & 3,125 & - & 6,25 \\
\hline Escherichia coli (7) & 6,25 & 3,125 & - & 1,56 & 25 & 3,125 & 12,5 & 6,25 & - & 6,25 & - & 6,25 & - & 6,25 & - & 6,25 \\
\hline Escherichia coli (8) & 6,25 & 3,125 & - & 1,56 & - & 3,125 & 25 & 1,56 & - & 6,25 & - & 3,13 & - & 3,125 & - & 3,13 \\
\hline Escherichia coli (9) & 6,25 & 1,56 & - & 6,25 & 25 & 3,125 & 12,5 & 1,56 & - & 3,13 & - & 6,25 & - & 3,125 & - & 6,25 \\
\hline Pseudomonas aeruginosa (1) & 6,25 & 3,125 & - & 6,25 & 25 & 3,125 & 12,5 & 0,78 & - & 1,56 & - & 3,13 & - & 3,125 & - & 6,25 \\
\hline Pseudomonas aeruginosa (2) & 12,5 & 6,25 & - & 6,25 & 12,5 & 6,25 & 12,5 & 6,25 & - & 3,13 & - & 6,25 & - & 3,125 & - & 6,25 \\
\hline Acinetobacter Baumanii (1) & 12,5 & 3,125 & - & 1,56 & 25 & 1,56 & 6,25 & 3,125 & - & 3,13 & - & 6,25 & - & 6,25 & - & 12,5 \\
\hline Acinetobacter Baumanii (2) & 6,25 & 3,125 & - & 3,125 & 25 & 3,125 & 6,25 & 6,25 & - & 1,56 & - & 6,25 & - & 3,125 & - & 6,25 \\
\hline Acinetobacter Baumanii (3) & 12,5 & 1,56 & - & 0,78 & 25 & 0,78 & 25 & 0,78 & - & 1,56 & - & 6,25 & - & 1,56 & - & 3,13 \\
\hline Acinetobacter Baumanii (4) & 6,25 & 6,25 & - & 1,56 & 25 & 3,125 & 12,5 & 6,25 & - & 6,25 & - & 12,5 & - & 6,25 & - & 6,25 \\
\hline staphylococcus aureus (1) & 6,25 & 3,125 & - & 6,25 & 25 & 3,125 & 12,5 & 1,56 & - & 12,5 & - & 12,5 & - & 3,125 & - & 6,25 \\
\hline staphylococcus aureus (2) & 6,25 & 3,125 & - & 6,25 & 25 & 3,125 & 6,25 & 3,125 & - & 12,5 & - & 12,5 & - & 6,25 & - & 3,13 \\
\hline
\end{tabular}

AE: aqueous extracts, ME: Methanolic extracts, DE: Dichloromethane extracts, EE: ethanolic extracts (-): no activity.

\subsection{The minimum bactericidal concentration of the extracts}

When the test was applied to determine the minimum bactericidal concentration and to number the surviving bacteria, it was suggested that for all the 
tested strains, no bactericidal activity was observed nor for all the tested extracts.

\section{Discussion}

In this study, we worked on the different ATCC strains, among which we find Staphylococcus aureus ATCC 25923, Escherichia coli ATCC 25922 and Pseudomonas aeruginosa ATCC 27853; they served as test microorganisms (quality control) [11].

The results of antibacterial activity of aqueous and methanolic extracts of Olea Europaea leaves from different regions are presented in Table 3.

It was noticed that both extracts had an inhibitory effect on all the tested organisms: but Gram-positive bacteria are more sensitive to the extracts than Gram-negative bacteria.

The aqueous extract of leaves from Meknes is the most active; it has a strong activity against all tested bacteria, with a maximum inhibitory zone for Methicillin-resistant S. aureus (MRSA) $(20 \mathrm{~mm})$ and a minimum inhibitory zone for $E$. Coli (8) with a diameter of (11 mm).

It is also active against ESBL bacteria: $E$. coli ( 1 and 3) and $P$. aeruginosa (1) with inhibition zones (16 $\mathrm{mm}$ and $14 \mathrm{~mm}$ respectively). It is effective against imipenem-resistant $A$. baumannii $(18 \mathrm{~mm})$ which are pathogenic germs of nosocomial origin.

The methanolic extract also showed activity against the different microorganisms tested, it has the highest inhibitory potential on imipenem-resistant $A$. baumanii (4) and multiresistant S.aureus (2) with inhibitory zones (16 $\mathrm{mm}$ and $15 \mathrm{~mm}$ respectively). It is effective against $\mathrm{P}$. mirabilis (2) ESBL and $P$. aeruginosa (1) ESBL by $12.25 \mathrm{~mm}$ and $11.5 \mathrm{~mm}$ respectively.

The MIC of the aqueous and methanolic leaf extracts on the tested bacterial isolates is presented in Table 5. The observed MIC from the aqueous and methanolic leaf extract is 12.5$50 \mu \mathrm{g} / \mathrm{ml}$ and 1.56-12.5 $\mu \mathrm{g} / \mathrm{ml}$ respectively, thus showing that the plant extracts are effective on the tested bacteria.

From the analysis of the results recorded in Table 4 and 5, we reported that the dichloromethane and hexane extracts of olive
For this reason, we can say that our extracts are bacteriostatic.

leaves studied in this work shows no inhibitory effect on all tested bacteria.

The ethanolic extract is active against all tested bacteria by a maximum inhibition zone for staphylococcus aureus ATCC $(17 \mathrm{~mm})$ which was shown by Meknes extract, while the minimum inhibition zone is reported for klebsiella pneumoniae (1) $(9 \mathrm{~mm})$. It is also active against ESBL bacteria: Proteus Mirabilis (2) and Pseudomonas aeruginosa (1) with inhibition zones $(15 \mathrm{~mm}$ and $13 \mathrm{~mm}$ respectively) presented by the extract of fquih ben salah.

The MIC observed from the ethanolic extracts of the leaves is between 0.78 and $12.5 \mu \mathrm{g} / \mathrm{ml}$, showing that our olive leaf extracts are effective on the bacteria tested with a small dose.

On the other hand, ethyl acetate extract is active against all the bacteria tested by a maximum inhibition zone observed against Citrobacter Freundii ATCC 8090 (30 mm), this zone is presented by the extract of Meknes, while the minimum inhibition zone is against Escherichia coli $(5)(10 \mathrm{~mm})$ presented by the extract of Ouezzane

Ethyl acetate extract is also active against ESBL bacteria: klebsiella pneumoniae (2) and Proteus Mirabilis (2) by one of inhibition (20 $\mathrm{mm}$ ) for both bacteria, and which is presented by Meknes extract. In addition, it has a high activity against Acinetobacter Baumannii (1) and (4) resistant to Imipenem with a zone of inhibition for both bacteria ( $25 \mathrm{~mm}$ and $22 \mathrm{~mm}$ respectively).

The MIC observed from ethyl acetate leaf extracts is 0.78 to $12.5 \mu \mathrm{g} / \mathrm{ml}$.

For all the strains tested, bactericidal activity was not observed for any extract used. Finally, we can say that all our extracts are bacteriostatic.

The results obtained in this study indicated the antibacterial efficacy of aqueous and methanolic extracts of O. Europaea leaves on tested isolates. A major challenge of using water for extraction is that non-polar bioactive compounds cannot be extracted [12]. 
Morteza Azizollahi reported that the aqueous extract of olive leaves showed good antibacterial capabilities and maximum inhibition of $11.5 \mathrm{~mm}$ against Salmonella typhimurium PTCC 1639[13].

Peter Masoko and David M. Makgapeetja showed that out of nine solvents used, methanol was the excellent extractant, as it carried out a larger amount of plant material than the other solvents used [11].

In addition, the minimum inhibitory concentrations observed from the methanolic extract of the leaves are between 1.56 and 12.5 and between 12.5 and $50 \mathrm{mg} / \mathrm{ml}$ for the aqueous extract. The results of our study have a similarity between several other studies [15], [16].

The bactericidal effect (minimum bactericidal concentration) of aqueous and methanolic extracts were not detected in our work; this result is similar to a result presented in the study conducted by Daoud Ziad et al [14].

In our study, Staphylococcus aureus was found to be the most sensitive microorganism, presenting a maximum zone of inhibition (20 $\mathrm{mm})$.

The successful inhibition of this bacterium and its contemporary etiology of gastroenteritis is a good development, especially when considering the appearance of its resistance to various conventional antibiotics [17], [18][19].

This is consistent with previous studies reporting that the spectrum of antibacterial activity varied depending on the type of extract and the Gram of the bacteria. Nevertheless, Gram-positive bacteria are globally the most sensitive to the effects of these polyphenolic extracts.

This generally higher resistance in Gramnegative bacteria is attributed to the presence of an outer lipopolysaccharide membrane impermeable to lipophilic compounds.

The absence of this barrier in Gram-positive bacteria favors direct contact of hydrophobic constituents of the extracts with the phospholipid bilayer of the bacterial cell membrane, resulting in increased ionic permeability and leakage of vital intracellular constituents or denaturation of bacterial enzyme systems [20], [21].
Therefore, these aqueous and methanolic extracts have hydrophilic properties and can subtilise Gram negative bacterial cells.

In a study conducted by Galal Al Askari et al. at the National Institute of Hygiene, they tested the antibacterial activity of Vitis vinifera leaves collected from different regions of Morocco (Fez, Meknes, El Jadida, Skhirat and Marrakech) against several bacteria such as Escherichia coli, klebsiella pneumonia, Pseudomonas aeruginosa, Acinetobacter Baumanii and Staphylococcus aureus.

They approved that aqueous and ethanolic extracts of Vitis vinifera leaves from different regions have good activity against Grampositive more than Gram-negative [22].

$\mathrm{N}$. Benayad et al. performed another study at INH on the same range of bacteria with different essential oil extracts and some extracts of Cistus ladaniferus from Oulmes in Morocco; they noticed that methanolic and aqueous extracts had strong antibacterial activity against these strains [23].

This is in agreement with a previous study indicating that the highest antibacterial activity against ESBL-producing bacteria was mainly manifested by Olea europaea [14].

The MIC observed from ethanolic extracts is 0.78 to $12.5 \mu \mathrm{g} / \mathrm{ml}$, which shows that these extracts have a very remarkable effectiveness on all these bacteria. Daoud Ziad postulated that the results showed significant inhibition with MICs ranging from 3.125 to $6.250 \mathrm{mg} / \mathrm{ml}$ [14].

It could be said that the nature and composition of the solvent, the ratio between the volume and mass of the solvent, the pressure and temperature of extraction, the number of extraction cycles and the duration of each cycle are factors influencing the efficiency of the extraction. The majority of pressurized liquid extraction applications reported in the literature use organic solvents, specifically ethanol and water [24].

Some researchers explained that oleuropein, which is included in these products, has many pharmacological properties, including antioxidant, antimicrobial, antiviral activities...

They also mentioned that the zones of inhibition that have a diameter of less than $12 \mathrm{~mm}$ were considered to have low antibacterial activity. The diameters included between 12 and $16 \mathrm{~mm}$ 
were considered moderately active and those above $16 \mathrm{~mm}$ were reported as highly active [15].

In relation to this situation, our ethyl acetate extract from Meknes is very active towards the majority of the tested bacteria

This result correlates with the study conducted by Daoud Ziad et al, they showed that ethyl acetate extracts of all the selected plants, showed a very potent antibacterial activity against Escherichia coli producing extended spectrum betalactamase and Klebsiella pneumoniae [14].

Furthermore, Altaf Hussain et al confirmed that the maximum activities were found for methanolic extracts in both plants against both types of bacterial strains. This could be due to the good extraction efficiency of methanol compared to other solvents, as it allows the extraction of whole phenolic compounds. The second and third effective solvents were ethanol and water, respectively.

Other extracts of (ethyl acetate, n-hexane, chloroform, and diethyl ether) had no significant difference regarding activities against the selected bacterial strains [25]

In the two previous studies, these results can be explained by the fact that, like many natural products, the variation in effectiveness due to differences such as geographical location, plant nutrition. It can be suggested that the collection site affects the antimicrobial activity in relation to the soil composition.

The results of our study, have a similarity between other studies regarding the antibacterial activity of olive leaf extracts [26], [27], [28].

\section{Conclusion}

The data obtained in this study reveal that the use of olive leaves can reduce the risk of bacterial infections, especially in the intestinal and respiratory tracts. The observed antibacterial effects of these medicinal plants on the microorganisms used, although in-vitro, seem interesting and promising and may be effective as a potential source of new antibacterial drugs. Further research is needed to obtain information regarding the practical effectiveness of Olea europaea $L$. extracts in inhibiting the growth of a broad spectrum of bacteria under specific application conditions.

\section{References}

1. Z. Mennane, A. Qasmaoui, H.L. Sahraoui, K. Halout, J. Hamamouchi, K. Khedid, R. Bahbah, M. Bourchid, N. Baghdadi, and R. Charof. Phenotypic and genotypic profile of isolated hospital enterobacteria from four Moroccan hospitals during 2011 and 2012. International Journal of Innovation and Applied Studies ISSN 2028-9324 Vol. 15 No. 1 Mar. pp. 55-60, 2016.

2. Mariam Fadli, Asmaa Saad, Sami Sayadi, Jacqueline Chevalier, Nour-Eddine Mezrioui, Jean-Marie Pagès, Lahcen Hassani. Antibacterial activity of Thymus maroccanus and Thymus broussonetii essential oils against nosocomial infection - bacteria and their synergistic potential with antibiotics. Phytomedicine 464-471, 19 (2012).

3. F. Demirc, K. Guven, B. Demirci, M.Y. Dadandi, K.H.C. Baser. Antibacterial activity of two Phlomis essential oils against food pathogens. Food Control 1159-1164, 19 (2008).

4. Altaf Hussain, Iqbal Ahmad Qarshi, Rabia Liaqat, Saeed Akhtar, Irum Aziz, Ikram Ullah, and Zabta khan Shinwari. Antimicrobial Potential of Leaf and Fruit Extracts and Oils of Wild and Cultivated Edible Olive. Pak. J. Bot., 46(4): 1463-1468, 2014.

5. Pereira A.P, Ferreira I.C.F.R, Marcelino F, Valentao P, Andrade P.B, Seabra R, Estevinho L, Pereira P.A. Phenolic compounds and antimicrobial activity of olive (Olea europaea L. $\mathrm{Cv}$ Cobrancosa) leaves. Molecules.12, 11531162; 2007.

6. Dub AM, Dugani AM. Antithrombotic effect of repeated doses of the ethanolic extract of local olive (Olea europaea L.) leaves in rabbits. Libyan J Med; 8:20947, 2013.

7. Nongpanga, K., W. Aporn, M. Duangtip and T. Sukon. Screening and identification of lactic acid bacteria producing antimicrobial compound from pig gastrointestinal tracts. Kmitl Sci. Tech. J., 8: 1, 2008.

8. Eloff, J.N, Asentitive and quick micro plate method to determine the minimal inhibitory concentration of plant extracts for bacteria. Plant Medical, 64: 711-713, 1998.

9. Janssen, M. A., Scheffer, J. J. C., \& Svendsen, A. B. Antimicrobial activities of essential oils: A 1976-86 literature review on possible 
applications. Pharmaceutische Weekblad (Scientific Edition), 9, 193-197, (1987).

10. Clinical and Laboratory Standards InstituteM07-A8. Methods for Dilution Antimicrobial Susceptibility Tests for Bacteria That Grow Aerobically, 2008.

11. Peter Masoko and David M. Makgapeetja, "Antibacterial, antifungal and antioxidant activity of Olea Africana against pathogenic yeast and nosocomial pathogens," BMC Complement. Altern. Med., vol. 15, p. 409, 2015.

12. M. L. Masoko P, Mokgotho MP, Mbazima VG, "Biological activity of Typha capensis (Typhaceae) from Limpopo Province (South Africa)," Afri J Biotechnol, vol. 20, pp. 3743-8, 2008.

13. G. R. Morteza Azizollahi Aliabadi, Reza Kazemi Darsanaki, Mahdiyeh Laleh Rokhi, Maryam Nourbakhsh, "Antibacterial activity of olive leaf aqueous extract," Ann. Biol. Res., vol. 3, no. 8, pp. 4189-4191, 2012.

14. A. E. and A.-M. R. Daoud Ziad, "Antibacterial Activity of Rheum Rhaponticum, Olea Europea and Viola Odorata on ESBL Producing Clinical Isolates of Escherichia Coli and Klebsiella Pneumoniae," IJPSR, vol. 2, no. 7, pp. 16691678, 2011.

15. E. T. A. Ö. Mukadderat Gökmen, Recep Kara, and Levent Akkaya, "Evaluation of Antibacterial Activity in Olive (Olea Europea) Leaf Extract," Am. J. Microbiol., vol. 5, no. 2, pp. 37-40, 2014.

16. A. Voss, "Staphylococcus aureus, PanEuropean antibiotic resistance and infection control," Chemother. J., vol. 5, pp. 5-6, 1996.

17. B. Wiedemann, "Epidemiology, control and treatment of multi-resistant Gram-negative rods," Drugs, vol. 52, pp. 95-100, 1996.

18. G. A. J. Ayliffe, "the progressive intercontinental spread of methicillin-resistant Staphylococcus aureus," Clin. Infect. Dis., vol. 24, pp. 74-79, 1997.

19. G. S. Mastoraki A, Kriaras I, -Douka E, Mastoraki S, Stravopodis G, "Methicillinresistant Staphylococcus aureus preventing strategy in cardiac surgery," Interact. Cardiovasc. Thorac. Surg., vol. 7, p. 452e6, 2008.
20. K. A. Khan R, Islam B, Akram M, Shakil S, Ahmad A, Manazir A.S, Siddiqui M, "Antibacterial activity of five herbal extracts against multi drug resistant (MDR) strains of bacteria and fungus of clinical origin," Molecules, vol. 14, pp. 586-597, 2009.

21. W. C. et S. M., "Inhibition of amino acid decarboxylase activity of Enterobacter aerogenes by active components in spices," $J$. Food Prot., vol. 58, pp. 280-283, 1995.

22. R. C. and Z. M. Galal Al Askari, Azzeddine Kahouadji, Khadija Khedid, Mahjouba Mousaddak, Laila Ouaffak, "Evaluation of AntibacterialActivity of Aqueous and Ethanolic Extracts of Leaves of Vitis vinifera Collected from Different Regions in Morocco," Am. J. Agric. Environ. Sci., vol. 12, no. 1, pp. 85-90, 2012.

23. M. M. N. Benayad, Z. Mennane, R. Charof, A. Hakiki, "Antibacterial activity of essential oil and some extracts of Cistus ladaniferus from Oulmes in Morocco," J. Mater. Environ. Sci., vol. 4, no. 6, pp. 1066-1071, 2013.

24. H. N. M. Z. Leila Abaza, and Amani Taamalli, "Olive Tree (Olea europeae L.) Leaves: Importance and Advances in the Analysis of Phenolic Compounds," Antioxidants, vol. 4, pp. 682-698, 2015.

25. A. Z. K. S. AltafHussain, IqubaL Ahmed Qarshi, Rabia Liquat, Saeed Akhtar, Irum Aziz, Ikram Ullah, "Antimicrobial potential of leaf and fruit extracts and oils of wild and cultivated edible olive," Pak. J. Bot., vol. 46, no. 4, pp. 1463-1468, 2014.

26. S. N. E. and S. Karakaya, "Olive tree (Olea europaea) leaves: potential beneficial effects on human health," Nutr. Rev., vol. 6, no. 11, pp. 632-638, 2009.

27. S. N. Malik., "Antibacterial Activity of Olive (Olea europaea) Leaves and Arugula (Eruca sativa) Seeds Extract," Int. J. Pharmacogn. Phytochem. Res., vol. 7, no. 2, pp. 307-310, 2015.

28. B. F. A. Ilias Faiza, Kholkhal Wahiba, Gaouar Nassira, Bekhechi Chahrazed, "Antibacterial and antifungal Activities of olive (Olea europaea L.) from Algeria," J. Microbiol. Biotech. Res., vol. 1, no. 2, pp. 69-73, 2011. 